\title{
Tourism Potential Assessment Model of the Monasteries of the Ibar Cultural Tourism Zone
}

\author{
Dragan PETROVIĆ1a, Danijela VUKOIČIĆa, Mirolju ${ }^{b}$ MILINČIĆ \\ aUniversity in Priština-Kosovska Mitrovica, Faculty of Sciences, Lole Ribara 29, 38220 Kosovska Mitrovica, \\ Serbia \\ ${ }^{b}$ University of Belgrade, Faculty of Geography, Studentski trg 3/3, 11000 Belgrade, Serbia
}

\begin{abstract}
The aim of this study is to determine and highlight the tourism potentials of the Ibar cultural tourism zone monasteries, which is located in the southwest part of Serbia. In the assessment of tourism potential, a quantitative model consisting of two groups of indicators (resource values and state of development) conceived of seven sub-indicators that were ranked and evaluated by respondents in the field, was applied. The results of the study show that the total tourist potential of the Ibar cultural tourism zone is 0.756 , which classifies it as an area with high potential. A substantial difference in grading can be noticed by comparing two groups of indicators. The value of the resource is 0.812 , and the value of the development state is 0.700 . The main value of the study is that for the first time, a model based on quantitative calculations is applied in order to determine the tourist potential of the Ibar cultural tourism zone monasteries. The study also highlights the advantages and disadvantages and contributes to better promotion and development of this area..
\end{abstract}

Key words: Quantitativemodel, tourist assessment, tourism potential, monasteries, Ibar zone, Serbia

\section{Introduction}

Tourism is a development indicator (Kelkay, Abunie, \& Sharma, 2019) and can make a significant contribution to economic growth, social functions and sustainable development if methodologically planned (Al Mamun \& Mitra, 2012). It also has a leading role in the promotion and international perception of the destination (Dupeyras \& Maccallum, 2013). The number of tourists has increased due to more leisure time, more income and high mobility, a result of increased car ownership, national and international road/sea/air public transportation systems and information technology (Kelkay, Abunie, \& Sharma, 2019). Regionsthat until recently had a poorly developed tourism industry are increasingly investing in tourism, in an effort to strengthen their economies(Drakulić Kovačević et al., 2018). As a result, the number of tourist destinations and competitiveness in the tourist market is constantly growing.

When tourism is taken as a whole, the importance of a tourist destination is emphasized. Defining the term tourist destination is not easy. It can be viewed as a changing, dynamic, adaptive and complex system of different and interconnected components (economic, social and environmental) whose key characteristic is the complexity that affects the dynamic state of tourism as a whole (Provenzano \& Baggio, 2019). In fact, a tourist destination encompasses different types of spatial units, most often local and regional, then national, and even continental in which tourist traffic takes place (Gunn,1998). These are places where tourists spend most of their time traveling. Tourism sites are crucial parts of successful tourism as tourism sites are the

\footnotetext{
${ }^{1}$ Corresponding author Dragan PETROVIĆ,; E-mail: draganpetrovicgagi958@gmail.com, Received:
} September 2020, Revised: October 2020, Published: November-December 2020 
destination points of a travel (Inchai et al., 2017). Gunn (1998) defines a destination as a geographical area with a critical mass of development that meets the needs of tourists and thus offers tourists the opportunity to take advantage of numerous attractions and services. In future, destinations should be viewed as parts of a broader system, which includes urban planning, economic inequality, transportation and accommodation, and "smart" initiatives among others (Fyall \& Garrod, 2019).

In order for the destination to achieve targeted competitiveness in the tourism market, it is necessary to distinguish the tourist resources, and determine the advantages and disadvantages of the destination. Tourism potential implies the ability of a location to attract and receive tourists taking into account the availability, quality and valorization of resources etc. (Anderson, 2007). In potential assessment, physical robustness and cultural significance represent one dimension, and market attractiveness and product design another. The integration of physical robustness in the assessment of potential, in parallel with the market attractiveness of heritage, represent the greatestadvantage of this model. The two-dimensional du Cros model also has its drawbacks. Namely, in presenting the results of the assessment, it often happens that cultural heritage is grouped with out forming a hierarchy of indicators (McKercher \& Ho, 2006). In order to improve this model, McKercher and Ho (2006) dismantled the existing framework, and added new factors. Thus, their model consists of four dimensions: cultural, physical, production and experiential values. Despite the attempt to differentiate the indicators by their importance, the model inherited certain weaknesses of the du Cros model. In order to address the shortcomings of the previous ones, Yan, Wendy Gao and Zhang (2017) developed a new quantitative model for assessing tourism potential. Based on the hierarchically cal culated value of indicators and subindicators, a comparison of the tourist potential at the location in a given area is performed.

Tourism potential is defined as "natural, cultural, historical and socio-economic value in total, used for the organization of tourism activities in a particular area" (Shohan, Toleuuly, \& Assadova, 2012:34). This term should not be understood solely from a resource-based perspective (Yan, Wendy Gao, \& Zhang, 2017). In order for the destination to maintain competitiveness in the tourist market, in addition to the identification of tourist resources, it is necessary to take into account its accompanying elements. Emphasis is placed on the needs of tourist locations in terms of facilities, services and infrastructure (Bassey, 2015).

Before placing a tourist destination on the market, it is necessary to know the potential of the site or relevant resources (Yan, Wendy Gao, \& Zhang, 2017). There are numerous studies which can help assess the tourism potential of different locations or resources. The corresponding impact of different indicators is very subjective and differs for different groups of visitors, so it is difficult to make an accurate and objective assessment (Drakulić Kovačević et al., 2018). The applicability of general models has not been analyzed in detail for local destinations, where specific problems may arise (Dwyer \& Kim, 2003). Small samples that can cause large errors in the results present a particularly big problem in statistical analyzes and derived conclusions.

There is no universal methodology in assessing tourism potential. A large number of studies apply the du Cros model (2001), which consists of two groups of indicators which consists of two groups of indicators. In potential assessment, physical robustness and cultural significance represent one dimension, and market attractiveness and product design another. The integration of physical robustness in the assessment of potential, in parallel with the market attractiveness of heritage, represents the greatest advantage of this model. The twodimensional du Cros model also has its drawbacks. Namely, in presenting the results of the assessment, it often happens that cultural heritage is grouped without forming a hierarchy of 
indicators (McKercher \& Ho, 2006). In order to improve this model, McKercher and Ho (2006) dismantled the existing framework, and added new factors. Thus, their model consists of four dimensions: cultural, physical, production and experiential values. Despite the attempt to differentiate the indicators by their importance, the model inherited certain weaknesses of the du Cros model. In order to address the shortcomings of the previous ones, Yan, Wendy Gao and Zhang (2017) developed a new quantitative model for assessing tourism potential. Based on the hierarchically calculated value of indicators and sub-indicators, a comparison of the tourist potential at the location in a given area is performed.

The goal of this study is to quantify the tourism potential of the six localities of the Ibar cultural tourism zone (Studenica, Žiča, Banjska, Gradac, Stara Pavlica, Nova Pavlica). An adjusted method, developed by Yan, Wendy Gao \& Zhang (2017), was used to quantify the tourism potential. The model uses ranking and scale techniques to evaluate the different attributes. The authors introduce a novelty in this paper by designing a matrix for graphical representation of this model's results. During the forming of various questions, it has been determined that there is a deficiency of credible quantitative data concerning the localities of the researched zone. The applied quantitative model helps rectifying the current situation caused by the dominance of qualitative methods in the tourism potential assessment. In accordance with the set goals, the primary assignments are to point out the advantages and the disadvantages of these localities and to use the quantitative results in creating plans and programs for further tourism development of the area.

\section{Research Area}

Ibar cultural-tourism zone is located in the southwest part of Serbia (Figure 1). It stretches from the city of Kosovska Mitrovica in the south, to the city of Kraljevo in the north; it follows the flow of the Ibar river and is the natural continuation of the Raska cultural zone. It encompasses the settlements: Kosovska Mitrovica, Zvecan, Leposavic, Raska and Kraljevo. As material remains from the Middle Ages, there are a large number of monasteries, churches and fortified towns in this area. They are characterized by a specific and original style of construction which was based on a combination of the Byzantine and Romanesque style elements (Raška school) (Tadić, 2012). In this region, the Studenica monastery stands out for its value, which has been on the UNESCO list of world cultural heritage since 1986 (Jovičić, 2009). The so-called golden age of Serbian fresco painting is related to this epoch (Radovanović et al., 2014).

Cultural significance in combination with natural and other resources in this area, makes the monasteries extremely attractive (Figure 2). Monasteries that represent immovable cultural goods of great and exceptional importanceand cultural monuments are under the protection of the Institute for the Protection of Cultural Monuments of Serbia, and that are located in this zone are: Studenica, Žiča, Banjska, Gradac, Stara and Nova Pavlica (Republički zavod za zaštitu spomenika kulture) (Table 1) (Figure 3).

Studenica Monastery is located in the settlement of Brezova and territorially belongs to the city of Kraljevo. It is $218 \mathrm{~km}$ away from Belgrade. It was being built from 1183 to 1196 (Popović, 2015). It was built by Stefan Nemanja, the founder of the Nemanjić dynasty. Due to its unique, original and exceptional artistic and cultural-historical values, the monastery was inscribed in the UNESCO World Cultural Heritage List in 1986 (Republički zavod za zaštitu spomenika kulture). The number of visitors to the monastery is great, especially during the summer months when numerous events are held in this part of Serbia, the most famous of which are 
"Lilac Days”, "Happy Run”, “Traditional Trumpet Festival”. People who attend these events, visit Studenica during their route.

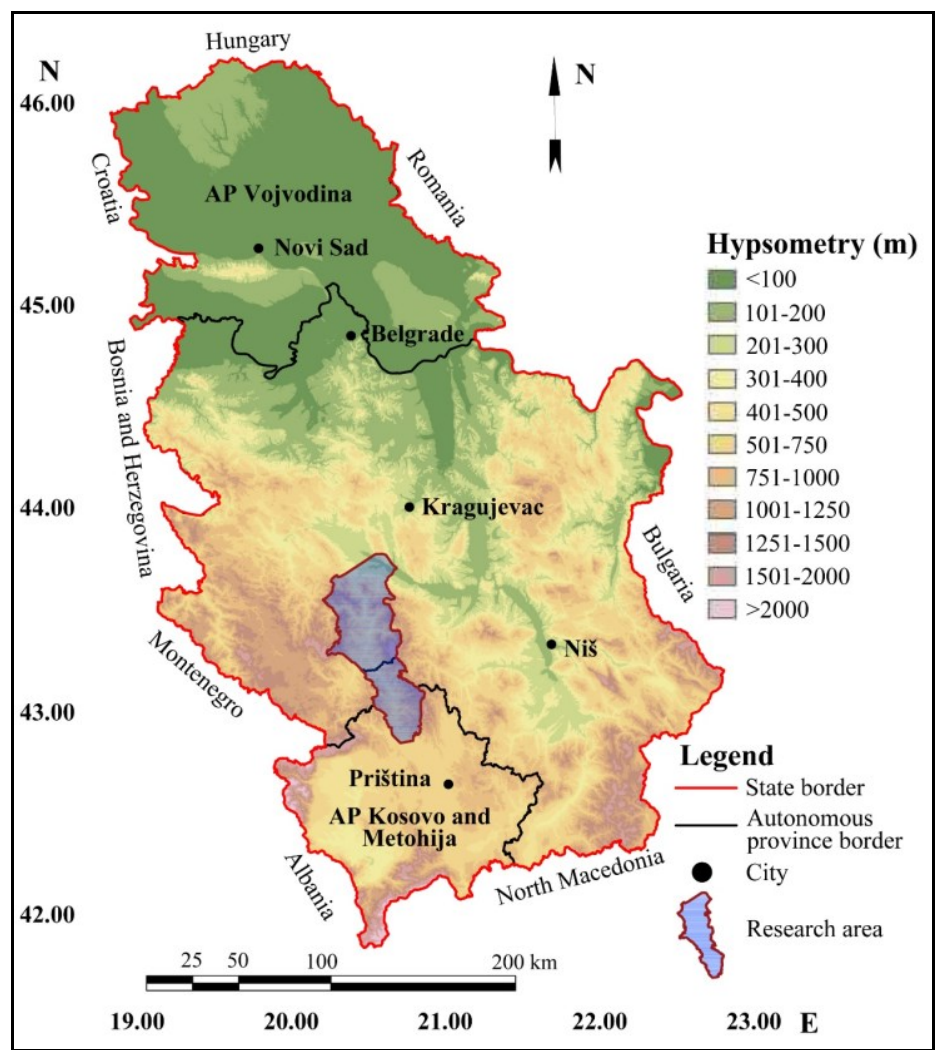

Figure 1. Location map of Ibar cultural tourism zone (Source: author's work 2020) (Source of hypsometry: CGIAR Consortium for Spatial Information, 2017).

Table 1. Basic information of the monasteries

\begin{tabular}{|c|c|c|c|c|}
\hline Monastery & Type & $\begin{array}{l}\text { Construction } \\
\text { period }\end{array}$ & Decision on the declaration & $\begin{array}{l}\text { Distance to } \\
\text { Belgrade in } \\
\text { kilometers }\end{array}$ \\
\hline Studenica & $\begin{array}{l}\text { Cultural } \\
\text { monument }\end{array}$ & $\begin{array}{l}\text { The end of the } \\
\text { 12th century }\end{array}$ & $\begin{array}{l}\text { The decision of the Institute for the } \\
\text { Protection of Cultural Monuments of Serbia } \\
\text { - Belgrade, no. } 421 / 47 \text { (23.10. 1947). }\end{array}$ & 218 \\
\hline Žiča & $\begin{array}{l}\text { Cultural } \\
\text { monument }\end{array}$ & $\begin{array}{l}\text { The beginning } \\
\text { of the 13th } \\
\text { century }\end{array}$ & $\begin{array}{l}\text { The decision of the Institute for the } \\
\text { Protection of Cultural Monuments of Serbia } \\
\text { - Belgrade, no. } 422 / 47 \text { (25.10.1947). }\end{array}$ & 169 \\
\hline Banjska & $\begin{array}{l}\text { Cultural } \\
\text { monument }\end{array}$ & $\begin{array}{l}\text { The beginning } \\
\text { of } 14 \text { th century }\end{array}$ & $\begin{array}{l}\text { The decision of the Institute for the } \\
\text { Protection of Cultural Monuments of Serbia } \\
\text { - Belgrade, no. 154/47(26.08.1947). }\end{array}$ & 295 \\
\hline Gradac & $\begin{array}{l}\text { Cultural } \\
\text { monument }\end{array}$ & $\begin{array}{l}\text { The end of } \\
\text { 13th century }\end{array}$ & $\begin{array}{l}\text { The decision of the Institute for the } \\
\text { Protection of Cultural Monuments of Serbia } \\
\text { - Belgrade, no. } 423 / 47 \text { (25.10.1947). }\end{array}$ & 243 \\
\hline $\begin{array}{l}\text { Stara } \\
\text { Pavlica }\end{array}$ & $\begin{array}{l}\text { Cultural } \\
\text { monument }\end{array}$ & $\begin{array}{l}\text { 11th or } 12 \text { th } \\
\text { century }\end{array}$ & $\begin{array}{l}\text { The decision of the Institute for the } \\
\text { Protection of Cultural Monuments of Serbia } \\
\text { - Belgrade, no. } 463 / 48 \text { (30. 03. 1948). }\end{array}$ & 234 \\
\hline $\begin{array}{l}\text { Nova } \\
\text { Pavlica }\end{array}$ & $\begin{array}{l}\text { Cultural } \\
\text { monument }\end{array}$ & $\begin{array}{l}\text { The end of the } \\
\text { 14th century }\end{array}$ & $\begin{array}{l}\text { The decision of the Institute for the } \\
\text { Protection of Cultural Monuments of Serbia } \\
\text { - Belgrade, no.351/48 (11.03.1948). }\end{array}$ & 233 \\
\hline
\end{tabular}

Source: (Republički zavod za zaštitu spomenika kulture) 
The Žiča Monastery is a symbol of the founding of the Serbian state, the autonomy of the Serbian church and national identity (Kesić Ristić, 2007). It is located at the foot of the mountain Stolovi, near the town of Kraljevo, $169 \mathrm{~km}$ south of Belgrade. It is the endowment of the first Serbian king, Stefan the First-Crowned. The construction of the main monastery church began in 1206 and was completed in 1217 (Kesić Ristić, 2007). Two churches have been preserved from the medieval monastery complex. Žiča is a nunnery with a sisterhood of 45 members. It is the most visited monastery in Serbia. The city of Kraljevo, as an emissive center, greatly influences the number of people who visit Žiča. The monastery is also an excellent starting point for touring the surrounding attractions, mountains (Goč, Stolovi, Radočelo), the medieval town of Maglič, the Ibar gorge, Mataruška Banja and others.

The Banjska Monastery is located at the foot of the Rogozna Mountain, not far from the Zvečan settlement. It is located $295 \mathrm{~km}$ away from Belgrade. The monastery was built between 1312 and 1316, as an endowment of King Stefan Milutin (Bogdanović, 1981). It was built on the model of Studenica. The monastery was abandoned in the second part of the 15th century (Bogdanović, 1981), its reconstruction has started in 2006 and the number of tourists has been increasing since then. There is a spa with the same name located in its vicinity, which has directly influenced to the rise in the number of tourists. The main limitation of the further development of this place is the unstable political situation in the area of the southern Serbian province.

Gradac Monastery, built in the period from 1277-1282, is located in the settlement of the same name and territorially belongs to the municipality of Raška, $243 \mathrm{~km}$ south of Belgrade. It represents the endowment of Queen Jelena. During the Turkish rule, the monastery was in poor condition, but the interior was largely preserved (Bogdanović, 1981). Two churches have been preserved within the monastery. The tourist position of Gradac is greatly influenced by the proximity of the tourist center Kopaonik, because the monastery in the tourist season is a significant starting point for excursionists, especially in the winter part of the year.

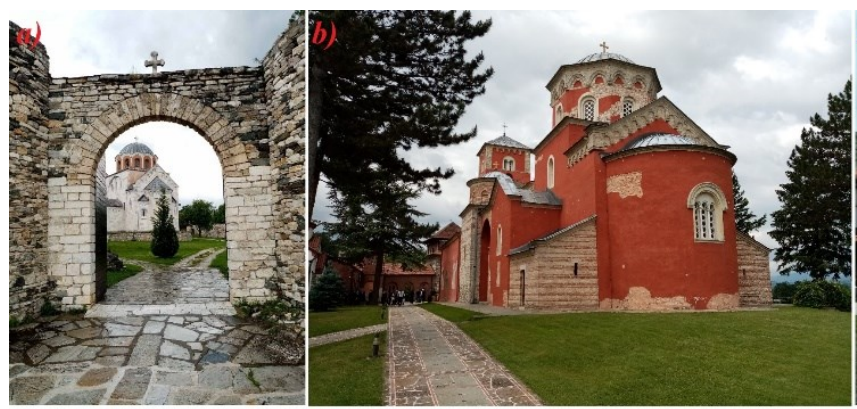

d) e)

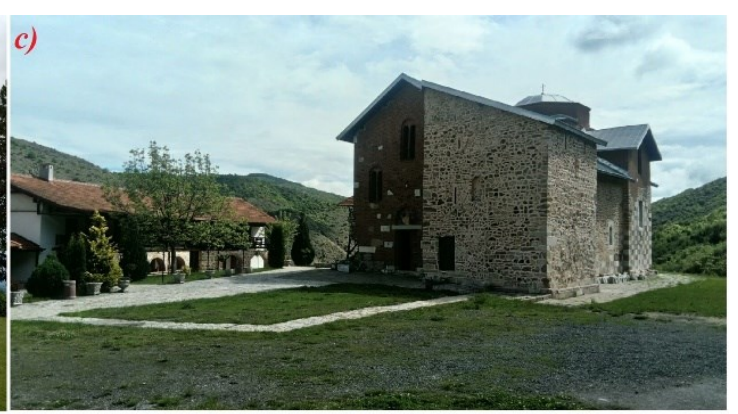

f)

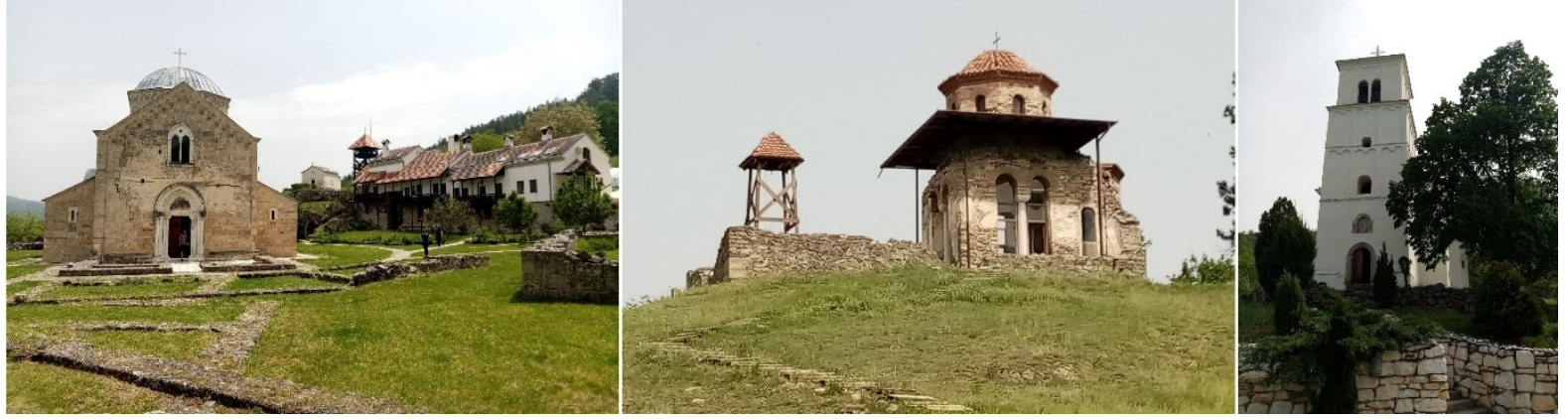

Figure 2. Monasteries of the Ibar cultural tourism zone: (a) Studenica; b) Žiča; c) Banjska; d) Gradac; e) Stara Pavlica; f) Nova Pavlica.) (Source: author's photos 2020). 
The monastery of Stara Pavlica was built probably in the 12th century, in the village of Pavlica and territorially belongs to the municipality of Raška. The founder of the monastery is unknown. It originates from the time before the reign of Nemanjić dynasty (Radovanović et al., 2014). During history, it has been desecrated several times. Renovation began in 1949. Today, there is a church within the monastery with a small number of preserved frescoes of high artistic value (Radovanović et al., 2014). The monastery records a low number of visitors.

Nova Pavlica Monastery is located on the right side of the valley of the Ibar, near the Stara Pavlica Monastery. It is the endowment of Stefan and Lazar Musić (Radovanović et al., 2014). It was erected and painted in the period from 1381-1386 in the Moravian style. The frescoes of the monastery are of high quality. It is $8 \mathrm{~km}$ away from the town of Raška and together with other values in the area it offers tourists a complete offer. Numerous ceremonies and festivals are held on the monastery grounds in the summer, when the monastery records the greatest number of visitors.

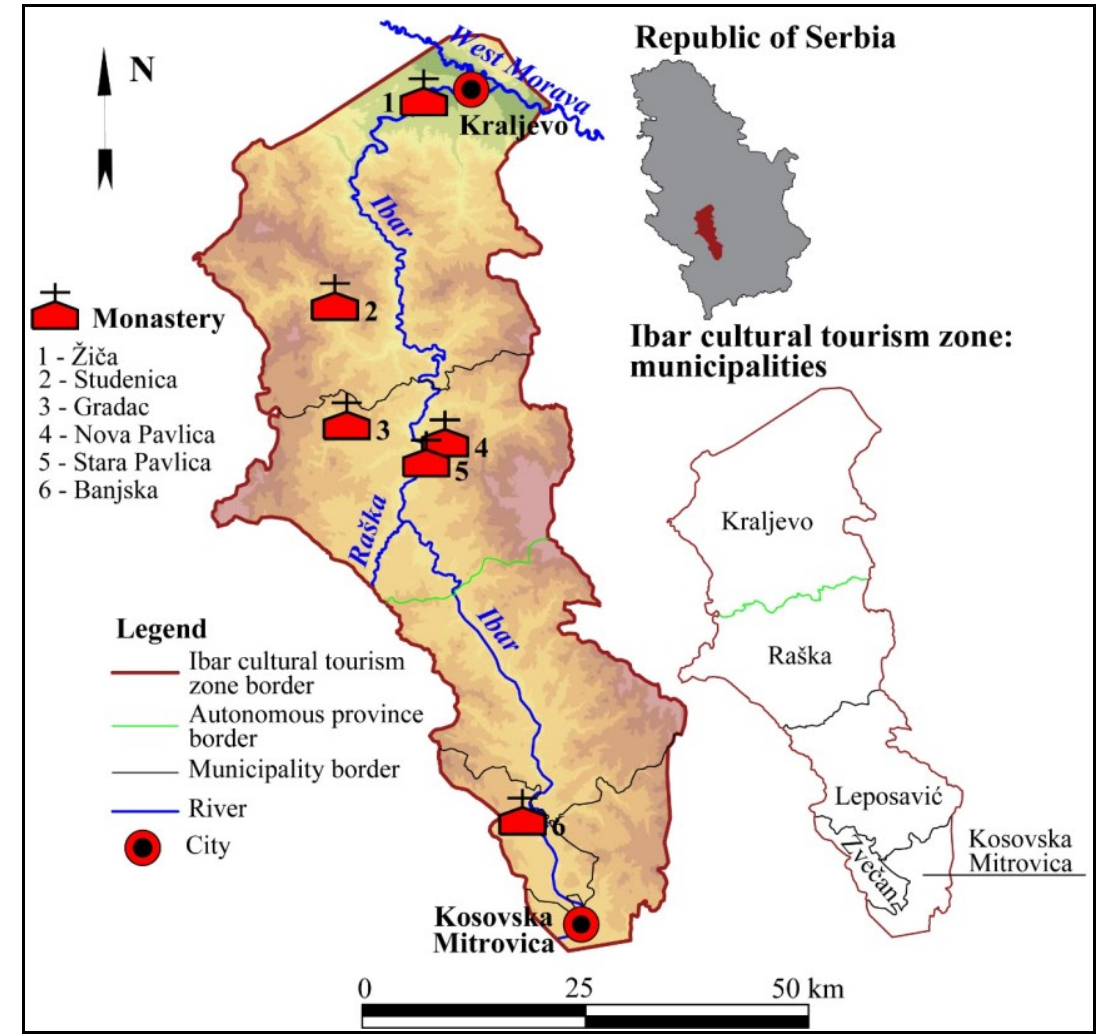

Figure 3. Locations of monasteries of Ibar cultural tourism zone (Source: author's work 2020).

\section{Methodology}

The assessment of tourism potential in this study was performed based on quantitative mathematical models developed and applied in order to evaluate the cultural heritage of selected rural settlements in China (Yan, Wendy Gao, \& Zhang, 2017) and to assess the tourist values of the UNESCO list of monasteries in Kosovo and Metohija (Ristić et al., 2020). For the sake of reliability and simplicity of displaying, the methodology has been presented in 5 consecutive steps.

The first step requires the authors to choose the indicators and sub-indicators which will then be ranked and rated by tourists. In the study, the assessment was performed on the basis of two indicators, the value of resources and the state of development, which consist of seven 
sub-indicators each (Ristić et al., 2020). Resource values were measured using the following seven sub-indicators: aesthetic value, historical value, level of awareness, ambience, complementarity with neighboringattractions (Li \& Lo, 2004), material value, and authenticity (McKercher \& Ho, 2006; Yeung, 2012). The state of development was measured on the basis of the following sub-indicators: accessibility, proximity to other attractions, tourist facilities (Li \& Lo, 2004), personal experience of the place, tourist information, time spent in the place (McKercher \& Ho, 2006), catering services (Sanchez Rivero, Sanchez Martín, \& Rengifo Gallego, 2016).

Every level 1 indicator consists of a set of variables (sub-indicators), which are considered level 2 attributes. After the indicators and sub-indicators have been acknowledged by the experts, in the second step the surveyors are introduced into the research. They are expected to rank the sub-indicators according to how they think they affect the tourism development $(1,2$, $3,4,5,6,7$ ), for both indicators separately, according to their preferences (Al Mamun \& Mitra, 2012). A larger number of respondents provide more reliable results. A sample of 720 subjects was used in this study. There are seven attributes for a group of 720 respondents. Thus, each respondent ranks the attributes from 1 to 7 (Al Mamun \& Mitra, 2012). For each attribute, the sum of all ranks will be 720 . Table 5 explains the procedure. In the conducted research, most respondents (420) chose attribute 1 as rank 1 , attribute 2 received the maximum number of votes for rank 2 , etc. Thus, the values are assigned in reverse of their ranks (Al Mamun \& Mitra, 2012), as 7, 6, 5, 4, 3, 2, 1 (Table 2). The sum of these numbers is 28. After assigning the value, the sum of all weights will be 1 (Al Mamun \& Mitra, 2012). Attribute 1 will get $7 / 28(0.250)$, attribute 2 will get $6 / 28(0.214)$, etc.

The measured value of each rank was calculated by the following formula:

$$
\boldsymbol{R}_{i}=(\boldsymbol{M A X}(\boldsymbol{i})+\mathbf{1}-\boldsymbol{i}) / \boldsymbol{\Sigma} \boldsymbol{I}
$$

Where i represents the ordinal number of the rank.

Table 2 explains the weighted average for the selected attributes.

Table 2. Weighted values for the sub-indicator ranks

\begin{tabular}{|c|c|c|}
\hline Resource value & Attributes & Importance \\
\hline Rank & Aesthetic value & $7 / 28=0.250^{*}$ \\
\hline 1 & Historic value & $6 / 28=0.214$ \\
\hline 2 & Awareness level & $5 / 28=0.179$ \\
\hline 3 & Ambiance & $4 / 28=0.143$ \\
\hline 4 & Material value & $3 / 28=0.107$ \\
\hline 5 & Authenticity & $2 / 28=0.071$ \\
\hline 6 & Complementarity with neighboring attractions & $1 / 28=0.036$ \\
\hline 7 & State of development \\
\hline \multicolumn{3}{|c|}{ Availability } \\
\hline 1 & The proximity of other attractions & $7 / 28=0.250^{*}$ \\
\hline 2 & Tourist facility & $6 / 28=0.214$ \\
\hline 3 & Personal experience of the place & $5 / 28=0.179$ \\
\hline 4 & Tourist information & $4 / 28=0.143$ \\
\hline 5 & Time spent in the place & $3 / 28=0.107$ \\
\hline 6 & Catering facilities & $2 / 28=0.071$ \\
\hline 7 & ${ }^{*}$ Cumulative rank value: $1+2+3+4+5+6+7=28$ \\
\hline
\end{tabular}

Source: (Own data 2020) 
To calculate the weight of the sub-indicator, all valid answers obtained from the survey were taken, and the weight of the sub-indicator was calculated by the following formula:

$$
W_{j i}=\Sigma\left(C_{j i} * R_{i}\right) / N
$$

Where $\mathrm{j}$ is a constant which refers to a given indicator, and represents the ordinal number of the sub-indicator, $\mathrm{Ci}$ is the number of occurrences of the $\mathrm{i}$-th rank for the given sub-indicator, and $\mathrm{N}$ is the sample size. The weight of the sub-indicator is shown in Table 5.

After determining the weighted values of attributes, the scaling of the attributes comes as step 3. Based on the quality or services used to evaluate every attribute, a periodic scale which incorporates 5 categories has been made. Each category has its own value, from a minimum of 1 to a maximum of 5 , and for ease of calculation, values from 0.2 to 1.0 have been taken ( $\mathrm{Al}$ Mamun \& Mitra, 2012; Yan, Wendy Gao, \& Zhang, 2017). Table 3 shows the assigned values of all categories.

Table 3. Value categories

\begin{tabular}{|l|l|l|l|l|l|}
\hline Mark & $1(0.2)$ & $2(0.4)$ & $3(0.6)$ & $4(0.8)$ & $5(1.0)$ \\
\hline Value & low & satisfactory & good & verygood & high \\
\hline
\end{tabular}

Source: (Al Mamun \& Mitra, 2012; Yan, Wendy Gao, \& Zhang, 2017)

In the fourth step, the authors assigned the importance to the indicators. Taking into account that the value of resources goes to the first place in the development of tourism, the attributes of the value of resources are ranked first, followed by the state of development (Table $6)$.

In the final step authors have grouped the attributes in two groups (resource value and state of development) and have calculated the tourism value potential of the places researched.

The total potential value of a resource is calculated by the following formula:

$$
V=\Sigma W_{j}\left(W_{j i} * S_{j i}\right)
$$

Where Sji is the mean score for the $\mathrm{i}$-th sub-indicator in $\mathrm{j}$-th set of indicators.

According to the results of tourism potential, the monasteries would fall into three categories: low potential $(\mathrm{V}<0.4)$, mean potential $(0.4 \leq \mathrm{V}<0.7)$ and high potential $(0.7 \leq \mathrm{V}<1)$ (Yan et al., 2017; Ristić et al., 2020).

\section{Results and discussions}

The questionnaires have been collected from January to March and from June to August 2020. The number of respondents who completed the survey questionnaire was 720 (Table 4), and the results were used to calculate the importance of the sub-indicator.

The time of research includes religious holidays and manifestations, when visits to monasteries are frequent. The questionnaires were managed by the authors, and the distribution was done on the spot. Data were collected on the basis of questions formulated using the Likert scale, focused on attitudes and satisfaction among monastery visitors. The tradition of these monasteries, their importance for Serbian culture as well as their tourist significance, was an incentive for every respondent. Data processing was performed in the IBM SPSS Statistics software (a program that loads data, performs analyzes, and provides printouts of results).

In order to calculate the mean values of the sub-indicators, the data set was divided into six subsets, according to the study places, and 120 questionnaires for each place. 
Of the total number of respondents, women accounted for $52.4 \%$ and men $47.6 \%$. Th e largest number of respondents is aged between 19 and 39 (51\%), followed by those aged between 40 and $59(27.9 \%)$, and those up to 18 years of age $(12.8 \%)$, while the smallest percentage are respondents were older than 60 (8.3\%). In terms of education, visitors with a high school diploma (41.5\%), followed by a university degree (25\%) predominate.

Table 4. Demographic structure of the respondents

\begin{tabular}{lll}
\hline & \multicolumn{2}{l}{ In total (N=720) } \\
\cline { 2 - 3 } Sex & $\mathrm{N}$ & Percentage (\%) \\
Male & 343 & 47.6 \\
Female & 377 & 52.4 \\
Age & & \\
Up to 18 years & 92 & 12.8 \\
19-39 years & 367 & 51.0 \\
40-59 years & 201 & 27.9 \\
Over 60 years & 60 & 8.3 \\
Level of education & & \\
Primary school & 75 & 10.4 \\
High school & 299 & 41.5 \\
College education & 134 & 18.6 \\
University & 180 & 25.0 \\
Master & 31 & 4.3 \\
Doctor & 1 & 0.1 \\
Means of transport to the site & & \\
car & 449 & 62.4 \\
bus & 271 & 37.6 \\
\hline \multicolumn{2}{l}{ Source: (Own data 2020) }
\end{tabular}

Source: (Own data 2020)

Visitors with primary education make up $10.4 \%$ and this percentage is followed by respondents over 60 years of age, as well as minors. The most common means of transport was a car $(62.4 \%)$, followed by a bus $(37.6 \%)$.

With the ordinal number of all sub-indicators, formula (2) was used to calculate the weight for the sub-indicators. Table 5 shows the ranking of sub-indicators and the results.

The results in Table 5 show that the high values in the group of resource values are the aesthetic value (iconostasis, altar, vault, frescoes) and the historical value. The values of these two sub-indicators are almost identical. Of medium importance is the level of awareness (importance in the education of young people), the environment and material value. Authenticity and complementarity with neighboring attractions are the two sub-indicators with low value.

In the group that determines the state of development, the accessibility sub-indicator is ranked first. It is accompanied by a personal experience of the place (experience during the visit). Sub-indicators of medium importance are the immediate vicinity of other attractions (theaters, museums, fairs, cultural events, and fairs), tourist information about monaste ries and tourist facilities nearby. Time spent in the place and catering facilities nearby is considered to be the least important parameters for development. Table 6 shows the analysis of the mean value for the two groups of sub-indicators, which referred to the value of resources and the state of development. 
By analyzing the sub-indicators that determine the value of resources, it was determined that the historical value is of great importance for all localities. Studenica and Žiča stand out with a high score of all parameters. During the analysis, certain similarities and differences between the investigated localities are noticed. The historic value, material value and the authenticity of the monasteries are highly rated. Studenica and Žiča have the highest material value, and Nova and Stara Pavlica have the lowest. The most authentic monasteries are Žiča and Stara Pavlica, whereas Nova Pavlica has low value of authenticity. The aesthetic value is high when it comes to Studenica and Žiča, while Stara and Nova Pavlica have extremely low values. In terms of valu es, the parameters of the ambience and the level of consciousness are similar, as well as the complementarity with the neighboring attractions, which has the lowest value among the first analyzed group.

Table 5. Display of ranks and weights of sub-indicators

\begin{tabular}{|l|l|l|l|l|l|l|l|l|}
\hline Sub-indicator & $\begin{array}{l}\text { Rang } \\
1\end{array}$ & $\begin{array}{l}\text { Rang } \\
2\end{array}$ & $\begin{array}{l}\text { Rang } \\
\text { An }\end{array}$ & $\begin{array}{l}\text { Rang } \\
4\end{array}$ & $\begin{array}{l}\text { Rang } \\
5\end{array}$ & $\begin{array}{l}\text { Rang } \\
6\end{array}$ & $\begin{array}{l}\text { Rang } \\
7\end{array}$ & Weight \\
\hline Aesthetic value (S15) & 420 & 42 & 78 & 36 & 54 & 54 & 36 & 0.200 \\
\hline Historic value (S11) & 180 & 336 & 48 & 60 & 42 & 36 & 18 & 0.197 \\
\hline Awareness level (S16) & 30 & 168 & 210 & 78 & 66 & 60 & 108 & 0.149 \\
\hline Ambience (S14) & 42 & 42 & 168 & 222 & 102 & 72 & 72 & 0.139 \\
\hline Material value (S12) & 18 & 78 & 96 & 108 & 168 & 180 & 72 & 0.121 \\
\hline Authenticity (S13) & 12 & 30 & 72 & 102 & 114 & 204 & 186 & 0.098 \\
\hline $\begin{array}{l}\text { Complementarity with } \\
\text { neighboring attractions } \\
\text { (S17) }\end{array}$ & 18 & 24 & 48 & 114 & 174 & 114 & 228 & 0.096 \\
\hline Total value of resources & & & & & & & & \\
\hline Availability (S22) & 354 & 96 & 96 & 66 & 60 & 42 & 6 & 0.201 \\
\hline $\begin{array}{l}\text { Personal experience } \\
\text { (S21) }\end{array}$ & 114 & 222 & 174 & 96 & 60 & 36 & 18 & 0.181 \\
\hline $\begin{array}{l}\text { The proximity of other } \\
\text { popular sites (S25) }\end{array}$ & 120 & 156 & 90 & 102 & 84 & 72 & 96 & 0.155 \\
\hline Touristinfo (S23) & 54 & 78 & 138 & 192 & 138 & 90 & 30 & 0.145 \\
\hline Tourist facilities (S24) & 60 & 84 & 126 & 120 & 156 & 126 & 48 & 0.139 \\
\hline $\begin{array}{l}\text { Time spent on the site } \\
\text { (S27) }\end{array}$ & 6 & 54 & 78 & 78 & 84 & 168 & 252 & 0.095 \\
\hline Catering facilities (S26) & 12 & 30 & 18 & 66 & 138 & 186 & 270 & 0.084 \\
\hline Total state of development & & & & & 1.00 \\
\hline
\end{tabular}

Source: (Own data 2020)

In addition to Studenica and Žiča, the Gradac monastery also has high values of subindicators that determine the development state. Banjska, Nova and Stara Pavlica have much lower values. The highest value for the Studenica monastery was given to the experience of this place during the visit. Accessibility parameters and tourist information for this monastery also have high values. Low values are assigned to the proximity of other attractions, tourist and catering facilities, as well as the desire to stay in the monastery. The monastery Žiča has almost identical values. Of the other monasteries, Gradac is ranked high. The most valued is the 
parameter of the experience of the locality. Mean values are assigned to accessibility, tourist information, proximity to other attractions, catering and tourist facilities, while visi tors are least interested in a longer stay in the monastery. Banjska has high values of the experience of the place, the average value for tourist information about the monastery, while the other parameters have low value. Stara and Nova Pavlica have almost identical low values of parameters concerningthe state of development. The experience of the place stands out for its importance, other values are low. Common to all monasteries is that they have a high value of experiencing the place, and low interest in a longer stay in them.

Table 6. Mean values of sub-indicators

\begin{tabular}{|l|l|l|l|l|l|l|}
\hline & Banjska & $\begin{array}{l}\text { Stara } \\
\text { Pavlica }\end{array}$ & $\begin{array}{l}\text { Nova } \\
\text { Pavlica }\end{array}$ & Gradac & Studenica & Žiča \\
\hline Sub-indicators & $\mathrm{N}=120$ & $\mathrm{~N}=120$ & $\mathrm{~N}=120$ & $\mathrm{~N}=120$ & $\mathrm{~N}=120$ & $\mathrm{~N}=120$ \\
\hline Historic value (S11) & 0.84 & 0.87 & 0.83 & 0.86 & 0.91 & 0.88 \\
\hline Material value (S12) & 0.83 & 0.81 & 0.81 & 0.84 & 0.90 & 0.89 \\
\hline Authenticity (S13) & 0.78 & 0.90 & 0.75 & 0.79 & 0.89 & 0.92 \\
\hline Ambience (S14) & 0.83 & 0.83 & 0.81 & 0.83 & 0.85 & 0.85 \\
\hline Aesthetic value (S15) & 0.82 & 0.66 & 0.70 & 0.84 & 0.88 & 0.87 \\
\hline Awareness level (S16) & 0.77 & 0.74 & 0.72 & 0.78 & 0.84 & 0.79 \\
\hline $\begin{array}{l}\text { Complementarity with } \\
\text { neighboring attractions } \\
\text { (S17) }\end{array}$ & 0.73 & 0.66 & 0.68 & 0.74 & 0.77 & 0.80 \\
\hline $\begin{array}{l}\text { Personal experience } \\
\text { (S21) }\end{array}$ & 0.85 & 0.86 & 0.85 & 0.85 & 0.88 & 0.86 \\
\hline Availability (S22) & 0.68 & 0.77 & 0.77 & 0.79 & 0.84 & 0.87 \\
\hline Tourist info (S23) & 0.73 & 0.66 & 0.66 & 0.78 & 0.82 & 0.80 \\
\hline Tourist facilities (S24) & 0.66 & 0.55 & 0.55 & 0.72 & 0.72 & 0.76 \\
\hline $\begin{array}{l}\text { Proximity of other } \\
\text { attractions (S25) }\end{array}$ & 0.61 & 0.49 & 0.51 & 0.72 & 0.73 & 0.73 \\
\hline Catering facilities (S26) & 0.69 & 0.48 & 0.50 & 0.70 & 0.67 & 0.73 \\
\hline $\begin{array}{l}\text { Time spent on the site } \\
\text { (S27) }\end{array}$ & 0.60 & 0.50 & 0.52 & 0.62 & 0.66 & 0.63 \\
\hline
\end{tabular}

Source: (Own data 2020)

The values of tourist potential for the six study locations were calculated using formula (3). Table 7 shows the values of the tourist potential of the studied places (Banjska, Stara Pavlica, Nova Pavlica, Gradac, Studenica, Žiča).

Table 7. Calculated value of the tourism potential

\begin{tabular}{|l|l|l|l|l|l|l|}
\hline Indicator & Banjska & $\begin{array}{l}\text { Stara } \\
\text { Pavlica }\end{array}$ & $\begin{array}{l}\text { Nova } \\
\text { Pavlica }\end{array}$ & Gradac & Studenica & Žiča \\
\hline Resource value & 0.800 & 0.784 & 0.758 & 0.810 & 0.861 & 0.857 \\
\hline $\begin{array}{l}\text { State of } \\
\text { development }\end{array}$ & 0.687 & 0.613 & 0.623 & 0.740 & 0.760 & 0.769 \\
\hline Total & 0.744 & 0.699 & 0.691 & 0.775 & 0.811 & 0.813 \\
\hline \multicolumn{7}{|c|}{15}
\end{tabular}


Source: (Own data 2020)

By analyzing Table 7, it can be concluded that in all six localities, the value of the development state is significantly lower than the value of resources, which indicates that the cultural heritage sites of the Ibar cultural tourism zone are insufficiently developed. Lower values for the state of development reduced the total potential value.

The total tourist potential of the Ibar cultural and tourist zone is $(0.756)$, which belongs to the category of high potential (Table 8) (Yan, Wendy Gao, \& Zhang, 2017; Ristić et al., 2020).

Table 8. Potential value scale

\begin{tabular}{|l|l|l|l|}
\hline Potential & low & medium & high \\
\hline Value & $<0.4$ & $0.4 \leq \mathrm{V}<0.7$ & $0.7 \leq \mathrm{V}<1$ \\
\hline
\end{tabular}

Source: (Own data 2020)

The values show that the following study places have a medium level of tourist potential: Nova Pavlica (0.691) and Stara Pavlica (0.699); Banjska (0.744) and Gradac (0.775) have higher level of tourism potential, while Studenica (0.811) and Žiča (0.813) have the highest (Figure 4 ).

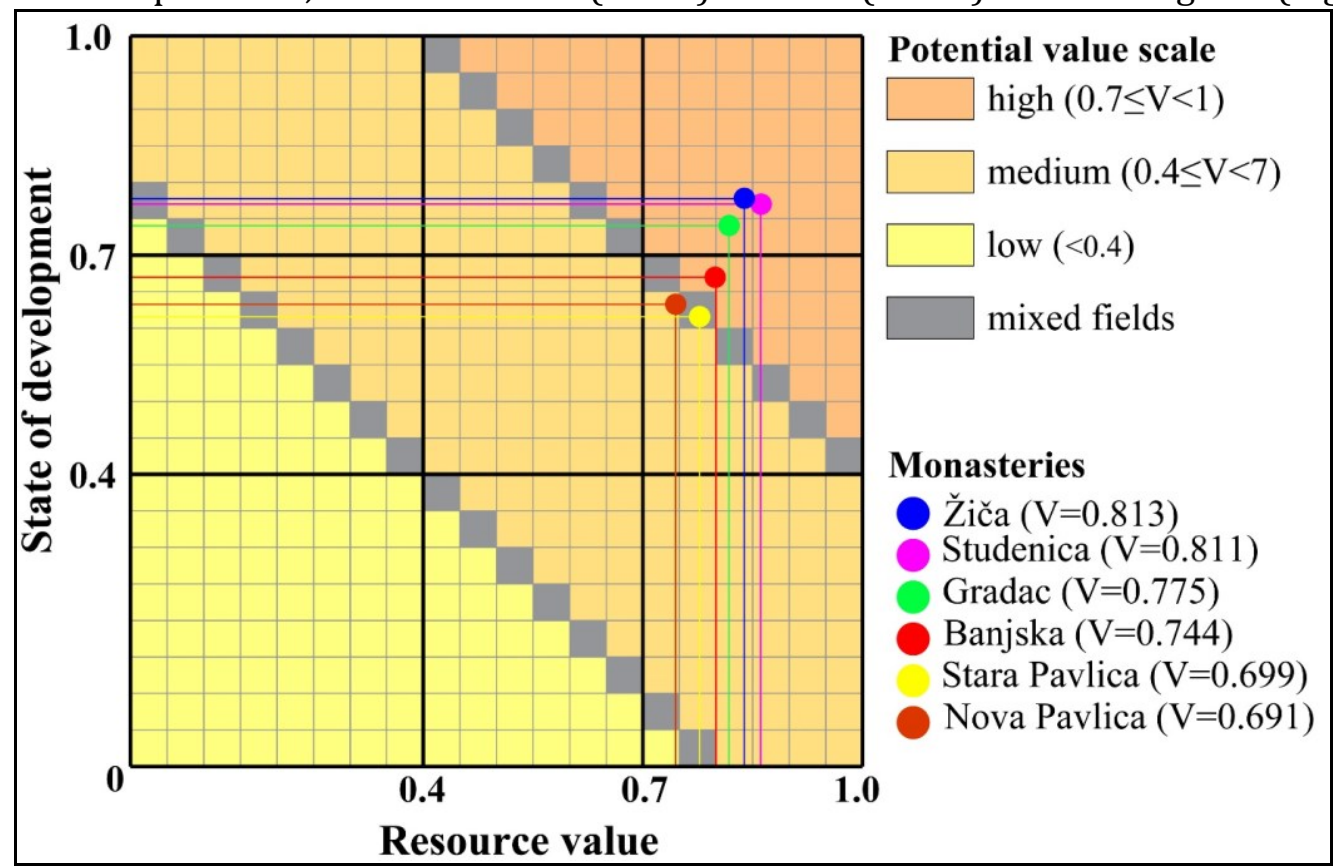

Figure 4. Matrix of potential value scale (Source: author's work 2020).

Figure 4 shows the graph which was used by authors to present the results of this research. The grey fields have transition values, and depending on the results, every field has different values.

Žiča has the greatest tourist potential among the studied monasteries. The most important parameters for its development are historical value, authenticity, material value, as well as the proximity of large emissive centers (Kraljevo). Near the monastery there is a highway that connects the northern with the southern parts of the country (Ibar highway), so the accessibility to the monastery is extremely good. Given the importance of this monastery for national culture and history, there is a lot of information about Žiča at the local, regional, national and higher 
levels. There are numerous tourist and catering facilities nearby and the complementarity with the neighboring attractions is evident.

The Studenica Monastery stands out for its authenticity and aesthetic value. It has a rich collection of preserved frescoes from the 13th and 14th centuries. In 1986, UNESCO included Studenica in the World Heritage List, and there is numerous tourist information about the monastery. The desire to keep tourists is not expressed to the expected extent, and the lack of tourist and catering facilities in the vicinity contributes to that.

The high attendance of the Gradac monastery is largely related to its position. It represents a complementary touristvalue of the Golija Mountain, and at the same time a supplement to the tourist offer of Kopaonik. The proximity of Kopaonik is important because it is a significant starting point for tourists during the tourist season. The proximity of Jošanička Spa is also significant, in relation to which the Gradac monastery represents a complementary tourist value. Its affiliation with the Ibar cultural and tourist zone is also important for the tourist position of the monastery.

The Banjska Monastery, which due to its location suffered a turbulent past, began to decay very early. Nevertheless, it has an exceptional historical, ambience, aesthetic and material value. The political situation negatively affects the development of this cultural monument.

Stara Pavlica is the earliest built monastery of the researched area. It stands out from other monasteries due to its authenticity. The monastery was being ruined and damaged throughout history. Nova Pavlica is the last monastery built in the Ibar cultural and tourist zone. Unlike the others, it has less historical significance. It has a high ambience and material value.

\section{Conclusions}

The choice of attributes used for the research of the localities was of utmost importance for the application of the model. The findings of this study have some implications on the future studies. Based on this study and the discussions previously conducted, experts could fulfill the rankings of indicators and sub-indicators. The main significance of this study is that the quantitative model is used for the first time, which is based on the statistical calculations to determine the tourism potential of the localities of the researched area. Besides this, the model is fulfilled by introducing the matrix for graphical representation of results.

In the earlier researches of assessing the tourism potential (du Cros, 2001; McKercher \& Ho, 2006; Sanchez Rivero et al, 2016), the methodologies used lacked objectivity in the assessment. The main advantage of the methodology developed by them (Yan et al., 2017), which was used in this research, is that visitors are included in the site evaluation process with their own opinions, interests and needs, thus greater objectivity is achieved. In addition to many advantages, the applied model has its disadvantages. Ranking sub-indicators can be a difficult task for participants. Despite the ranking requirement, several participants rounded up the same values for different sub-indicators and research sites. Such alternative answers may cast doubt on the existence of a research hierarchy. In order to eliminate these shortcomings, it is necessary to include the opinion of experts in future research.

The total value of the tourist potential of the Ibar cultural tourism zone is high (0.756). According to the methodology used in the research, among the analyzed monasteries, Žiča has the highest value, and Nova Pavlica the lowest. What is noticeable is the large difference between the parameters of the value of the resource and the state of development. Great historical, material and aesthetic value, high degree of authenticity, as well as levels of awareness gives these sites a high tourist potential. Based on the results of the research, it is 
concluded that the main problems and obstacles to the further development of this area are the lack of promotional activities, quality and professional guide services as well as minimal and often poor infrastructure at the sites. A higher degree of valorization, primarily the construction of infrastructure, facilities near the monastery (hotels, restaurants, and cafes), greater tourist promotion by making brochures for lesser-known monasteries and greater interconnectedness of sites in this area, would lead to a much higher degree of development of Ibar cultural tourism zone.

\section{Resources}

1. Al Mamun, A., \& Mitra, S., 2012. A methodology for assessment of tourism Potential: Case study Murshidabad District, West Bengal, India. International Journal of Scientific and Research Publications, Vol. 2(9), p. 1-8.

2. Anderson, G., 2007. The living heritage survey of the designated buffer zone of the Ukhahlamba drakensberg world heritage site. Retrieved from: www.sahra.org.za.

3. Bassey, B. E., 2015. Transforming the Nigeria tourism industry through tourism entrepreneurial development. African Journal of Business Management, Vol. 9(15), p. $\underline{569} \underline{580}$. https://doi.org/10.5897/AJBM2015.7844.

4. Bogdanović, D., 1981. Preobražaj srpske crkve. Istorija srpskog naroda, Srpska književna zadruga, Beograd, Vol. 1, p. 315-327.

5. CGIAR Consortium for Spatial Information. SRTM 90m Digital Elevation Data. 2017. Retrieved from: http://srtm.csi.cgiar.org/ (accessed: 22 February 2017).

6. Drakulić Kovačević, N., Kovačević, L., Stankov, U., Dragićević, V., \& Miletić, A., 2018. Applying destination competitiveness model to strategic tourism development of small destinations: The case of South Banat district. Journal of Destination Marketing \& Management, Vol. 8(1), p. 114-124.

7. Du Cros, H., 2001. A new model to assist in planning for sustainable cultural heritage tourism. International Journal of Tourism Research, Vol. 3(2), p. 165-170.

8. Dupeyras, A., \& Maccallum, N., 2013. Indicators for measuring competitiveness in tourism: A guidance document. OECD Tourism papers, Vol. 2013/2, p. 1-62.

9. Dwyer, L., \& Kim, C., 2003. Destination competitiveness: Determinants and indicators. Current Issues in Tourism, Vol. 6(5), p. 369-414.

10. Fyall, A., \& Garrod, B., 2019. Destination management: a perspective article. Tourism Review, Vol. 75(1), p. $165-169$.

11. Gunn, C. A., 1998. Vacationscape: designing tourist regions. New York: Van Nostrand Reinhold. https://doi.org/10.1177/004728758802700211.

12. Inchai, M., Tantranont, N., Kungwon, S., Nunthasen, W., \& Lo, Y.C., 2017. Evaluation of Recreational Benefit for Natural Tourism Quality Improvement in Mae Wang District, Chiang Mai, Thailand.Journal of Environmental and Tourism Analyses, Vol. 5(1), p. 5-19.

13. Jovičić, D., 2009. Turistička geografija Srbije, Univerzitet u Beogradu - Geografski fakultet, Beograd.

14. Kelkay, S., Abunie, Y., \& Sharma, S., 2019. Challenges of Sustainable Tourism Development in Jimma, Buno Bedele and Nekemt Town, Oromia Region, Ethiopia. Journal of Environmental and Tourism Analyses, Vol. 7(1), p. 16-27.

15. Kesić Ristić, S., 2007. Spomeničko nasleđe Srbije, nepokretna kulturna dobra od izuzetnog i od velikog značaja, Republički zavod za zaštitu spomenika kulture, Beograd.

16. Li, Y., \& Lo, R. L. B., 2004. Applicability of the market appeal robusticity matrix: A case study of heritage tourism. Tourism Management, Vol. 25(6), p. 789-800.

17. McKercher, B., \& Ho, P. S., 2006. Assessing the tourism potential of smaller cultural and heritage attractions. Journal of Sustainable Tourism, Vol. 14(5), p. 473-488.

18. Popović, M., 2015. Manastir Studenica arheološka otkrića, Republički zavod za zaštitu spomenika kulture - Arheološki institut, Beograd. 
19. Provenzano, D., \& Baggio, R., 2019. Quantitative methods in tourism and hospitality: a perspective article. Tourism review, Vol. 75(1), p. 24-28.

20. Radovanović, S., Stanojlović, A., Todorović, I., Matković, S., Roksandić, S., \& Todorović, T., 2014. Svi srpski manastiri, Magic map d. o. o., Vol. (1), Beograd.

21. Republički zavod za zaštitu spomenika kulture-Beograd. Baza nepokretnih kulturnih dobara. Retrieved from: http://www.spomenici.heritage.gov.rs/cir/pretraga (08.04.2020.)

22. Ristić, D., Vukoičić,D., Nikolić, M., Božović S., \& Milinčić, M., 2020. Tourismvalue assessment model of 'UNESCO-listed' monasteries: Kosovo and Metohija. Current Issues in Tourism, Vol. 23(17), p. 20982102.

23. Sanchez Rivero, M., Sanchez Martín, J. M., \& Rengifo Gallego, J. I., 2016. Methodological approach for assessing the potential of a rural tourism destination: An application in the province of Caceres (Spain). Current Issues in Tourism, Vol. 19(11), p. 1084-1102.

24. Shohan, R., Toleuuly, A., \& Assadova, Z. K., 2012. Tourist potential and prospects oftourism industry of Kazakhstan. Education and Science Without Borders, Vol. 3(5), p. 34-37.

25. Tadić, M., 2012. Crkve raške škole - monumentalni orijentiri (matematičko geografski pogled na orijentaciju crkava raške škole), Zbornik radova - Geografski fakultet Univerziteta u Beogradu, Vol.60, p. 193-204.

26. Yan, L., Wendy Gao, B., \& Zhang, M., 2017. A mathematical model for tourism potential assessment. Tourism Management, Vol. 63, p. 355-365.

27. Yeung, Y. M. E., 2012. Residents 'and tourists' perceptions on adaptation and authenticity of heritage buildings as a tourist product (Unpublished master's thesis). The Hong Kong Polytechnic University.

(C) 2020 by the authors. Submitted for possible open access publication under the terms and conditions of the Creative Commons Attribution-Non Commercial-No Derivatives (CC $\quad \mathrm{BY} \quad \mathrm{NC} \quad \mathrm{ND}) \quad 4.0 \quad$ International License. (https://creativecommons.org/licenses/by-nc-nd/4.0/). 